\title{
Multinational Enterprise and International Investment Law
}

\section{Conflict between International Investment Protection System and International Environmental Law}

\author{
Zhongkai $\mathrm{Niu}^{1, \mathrm{a},{ }^{*}, \dagger}, \mathrm{Yi} \mathrm{Wang}^{2, \mathrm{~b},{ }^{*}, \dagger}$, Tianhao $\mathrm{Wu}^{3, \mathrm{c}, *, \dagger}$ \\ ${ }^{1}$ Puyang No.1 Senior High School, Henan Province, China \\ ${ }^{2}$ School of Sendelta International Academy, Shenzhen, China \\ ${ }^{3}$ Fairfield Prep, Beijing China \\ *Corresponding author email: ${ }^{\text {axiaye624@gmail.com, }{ }^{b} \text { miwang@mentonegirls.vic.edu.au, }{ }^{c} p 23 t w u @ f a i r f i e l d p r e p . o r g}$
}

${ }^{\dagger}$ These authors contribute equally.

\begin{abstract}
The concept of sustainable development is completely global and new nowadays. The word of sustainable development is strongly agreed upon by all countries, including developing countries and developed countries, since it was presented. Economy and social life will be greatly changed by implementing the strategy of sustainable development, and the change and development of social existence must inflect the change and development of social ideology as social existence decides social ideology, and the law as the superstructure must also be inflected by it. International environmental law and international investment law, which is one of the most important branches of international economic law must make sense of sustainable development, too. Although sustainable development has not been accepted by international society universally as a basic principle of international economic law, it is sure that the acceptance just needs some time. Sustainable development is becoming one of the basic principles of international economic law. The shape of the theory of sustainable development has its social, economic, and legal foundation. To seek the development of economy, man has asked more from nature, and a series of problems come along with it, such as the pollution of the environment, the shortage of resources, etc, all these make people realize the importance of sustainable development. And with the increasing prosperity of international investment, there are many cases of multinational companies using the international investment protection system to evade the environmental law sanctions. Still, at present there is less attention to this problem, so this paper studies this problem through the analysis of relevant examples and tries to give some views to solve this problem.
\end{abstract}

Keywords: international investment protection system, environmental protection rules, conflict of laws.

\section{SUMMARY}

Investment liberalization has extensively promoted economic development; the public has seen its interests. Environmental protection as public social interests, longterm interests, people tends to be more willing to maximize the realization and safety of the immediate fundamental private rights - only environmental protection and other social public goods as a kind of protection Long-term goal[1]. As the essence of international investment, multinational companies are made up of overseas investors from developed countries.
They usually have muscular economic strength and political influence and strengthen the control and penetration ability of the host country. As spokesmen of developed countries, they actively promote investment liberalization and reflect investment-related agreements. In the host country, they enjoy more rights and bear fewer obligations, and the rights and obligations are often unbalanced. "The pursuit of high profits and mercenary nature make them conflict with the national interests and development goals of host countries." "They influence the decision-making of the host government, exert pressure on the government through multiple channels, 
and make the government's efforts to promote environmental protection significantly discounted or even frustrated, even in developed countries. To maximize their economic interests, sometimes private investors will sacrifice the environment, transfer pollution-intensive industries to countries with lower environmental standards, plunder the host country's resources, damage the public social interests of the host country. And in the longer term, it hurt the common public interests of human society without hesitation, which is contrary to sustainable development[2].

\section{INTRODUCTION}

The sustainable development concept is a new global development concept in the world, including economic sustainable development, socially sustainable development and ecologically sustainable development, which has covered the specific contents of sustainable production, development, utilization, life and consumption. The implementation of a sustainable development strategy will bring great changes to human society. It will not only change the way of economic growth but also walk out a path of coordinated development of economy, society, environment, population and resources, and will have a great impact on the law. "Law and law, as a system and theoretical system closely related to social life, must be promoted by sustainable development and changed." "Since sustainable development takes the whole of the earth as the research object, international law is particularly urgent to pay attention to this issue. In view of the fact that economic issues have become the main aspect of international communication as the core legal system for dealing with transnational economic relations, the international economic law should pay attention to, involve and reflect the value objectives and evaluation criteria of sustainable development.

As an important branch of international economic law, international investment law is closely related to environmental protection. Under the background of the development oriented era, multinational enterprises often influence the natural environment of host countries because of their excessive pursuit of maximum interests. Even using the international investment protection system to counter the international environmental law and the environmental management regulations of the host country, this kind of behavior not only has great harm to the host country environment but also has a very bad influence on the international community[3]. At present, scholars have not studied cross-border environmental management. The existing investment agreements have made a positive response to environmental protection, but the limitations can not be ignored, and cross-border environmental protection has not been paid due attention[4]. Therefore, this paper will start with the international investment protection system and discuss the promotion of multilateral investment legislation under environmental protection guidelines. This paper is mainly divided into three parts to elaborate on the conflict and coordination measures.

1. Outlines the causes, types, related treaties and provisions of conflicts

2. Introduce the specific cases of conflict, such as non-discrimination treatment in environmental protection, civil right in environmental protection measures and double standards in environmental protection

3. Discuss the potential problem of the impact of this conflict, Introduce the current situation of the problem.

\section{LITERATURE REVIEW}

The rapid development of multinational companies brings economic growth to the host country and accompanies various problems[5]. Scholars worldwide have also done much Research and Analysis to adjust the relationship between host countries and TNCs. In the past research on this issue, some scholars have studied the impact of multinational corporations on residents' land rights in the host country. Relevant works include largescale land investments in the least developed countries. From the perspective of law and economics, the author analyzes the "large-scale agricultural land investment" in African least developed countries, including the concept of land plunder, the participants and legal regulations of land take, and the impact of large-scale land investment on the property rights and food rights of residents, And the conflict between the protection of human rights of residents and the protection of investors in sub-Saharan Africa, and the dilemma of the regulation of large-scale land investment in international law. From the perspective of economics, this paper analyzes opportunism in land investment contracts and puts forward the mechanism to curb initiative[6].

There are also researches on the social responsibility of multinational enterprises, and the related works include[7].They can be roughly divided into four parts from the content of this paper. The first part is to explain the social responsibility system of multinational enterprises through historical Analysis and empirical Analysis. Firstly, from the connotation and concept of corporate social responsibility, this paper combs the historical development of corporate social responsibility theory and further clarifies the causes of corporate social responsibility, responsibility standards, specific content, and other issues. This part will combine the legislative practice of various countries and the documents and activities of international organizations and nongovernmental organizations to sort out the existing social rules of multinational enterprises. Finally, it will explain the shortcomings of the traditional way of regulating the 
social responsibility of global enterprises from the perspective of practice and theory.

Besides, there are also researches on the social insurance of employees in foreign enterprises. Related works include[8], because there are few participants in the research field. There are no monographs and reference materials. The author tries to make a preliminary analysis and research on employees' social insurance in foreign enterprises based on the actual situation of the social security service. This paper analyzes the current status of the problem and discusses social insurance characteristics for employees of foreign enterprises in China and the differences between the social insurance for employees of foreign enterprises. Besides, other social countermeasures and suggestions to improve the laws and regulations of social insurance for employees of foreign enterprises in China are also discussed in the paper. In this paper, the discussion and research on the social insurance problems of Chinese foreign enterprise employees play a role in attracting more valuable information. It makes a positive contribution to strengthening and improving the construction of the social insurance system of the host country.

At present, many scholars have done Research and Analysis on the problem of multinational corporations polluting the host country's environment. However, they pay more attention to land pollution, environmental pollution, air pollution, and other specific aspects and provide specific management measures and improvement ideas for cross-border ecological management. However, few people have studied how to coordinate the environmental relationship between multinational corporations and host countries. Therefore, this paper starts from the perspective of multinational corporations using international investment protection system to evade the sanctions of environmental law; this paper analyzes the current situation of cross-border environmental management problems between host countries and multinational companies and tries to find solutions to the issues through specific case analysis, to make efforts to coordinate the relationship between international investment protection system and international environmental law.

The main research methods of this paper are literature research methods, through books, newspapers, and other publications, as well as the network, to collect cases of multinational companies polluting the host country's environment, environmental protection information[9]. Case study method: Based on relevant resources, this paper points out the dilemma of the host country's environmental protection in international investment, analyzes the reasons combined with patients and seeks solutions. Comparative analysis research method: compare different pollution cases to find out the common points of this problem and summarize the conflict points between international investment protection regulations and international environmental law[10].

\section{CASE ANALYSIS}

\subsection{The India Bhopal Disaster}

The India Bhopal disaster was one the most severe tragedy in human history, caused by the Indian subsidiary of the American firm Union Carbide Corporation. On December 3, 1984, because of the harsh environment and the neglect of undertrained staff, a toxic and deadly gas called MIC (cyanide) release from a factory built in Bhopal, the capital of Madhya Pradesh India, were near a dense ghetto. This gas directly killed 25 thousand people, untold numbers of people have indirectly lost their lives, lost their eyesight, and children have been born with many deformities. The incident generated a great deal of international discussion. People realize the enormous environmental risks that MNES may bring to the host country and the conflict between the liability and international investment law. After this tragedy happened, thousands of Indian people and the government sued the Union Carbide Corporation in America. According to the holistic responsibility theory, the parent company and subsidiary will be one economic entity to take liability together in this theory.

Although the Indian subsidiary of the American firm Union Carbide Corporation is the subsidiary of the American parent company and manages, operates, and maintains by the Indian, the subsidiary may provide just a "tool" or representation of the parent company. And the subsidiary acts in the interest of the parent company. The Indian subsidiary's financial strength also prevents it from paying damages, while using the more prosperous parent company would better get injuries. The American parent company uses the vulnerability in law and takes double standard to transfer the environmental pollution in the home country to the host country. After the Indian Bhopal disaster happened, the Union Carbide Corporation in America tries to hide the truth by describes the incident as a negligent act. However, it was evident that the geographical environment, hardware, and software facilities are seriously substandard in the Bhopal factory. However, the parent company still lowered the management standards and shortened the staff training time for its benefit, which led to the tragedy. In this case, the American parent company advocates the principle of limited liability. The parent company and the subsidiary are independent individuals, so the parent company should not assume the subsidiary's debts. However, such a rule is very likely to lead to the parent company taking advantage of its loopholes to damage the interests of the legal person of the subsidiary because the parent company's control of the subsidiary's equity will make the subsidiary its incarnation. This legal loophole that the parent company used to reduce its damages in the Bhopal 
gas case. Even with the indelible consequences of the disaster, the US courts rejected the Indian people and government's appeals as forum inconvenient, indirectly declaring a victory for the US parent company. Through the way of negotiations, the Indian government and Union Carbide Corporation have a contract. The Union Carbide Corporation paid $\$ 470 \mathrm{~m}$ to the Indian government, most of which produced by the parent company. That's a drop in the bucket compared to the amount of money they paid. The average victim received less than 1,000, and years later, many victims still didn't get what they were supposed to get. In this case, MNES' parent company takes advantage of the law, using subsidiaries as their stand-ins damaging the environment in host countries by unethically reducing their payouts. The courts were also standing up for them. The saddest thing is that Anderson, the parent's company boss, escaped unhurt and was not punished at all, which reflects the loopholes in the law for MNEs and the light degree of punishment[11].

\subsection{Terrell Smelter Arbitration}

Terrell Smelter Arbitration shows better that how important the law is and how global pollution occurs. Terrell Smelter Arbitration happened in the last century, and a Canadian lead and zinc smelter caused it. This factory builds in Canada. However, it was close to America. After 30 more years, this factory kept releasing the sulfide and did a lot of damage done to the American state of Washington. The residents in America that had been affecting try to sue the factory to get their injuries, however, it was impossible, and until 1983, with the help of the United States government, Canada and the United States initiated arbitration, and finally awarded Canada $\$ 78,000$ to the United States. And in the second judgment in 1941, trans-border environmental pollution was defined as illegal in this judgment, and this case has become an essential indicator for judging environmental liability abroad[12].

In this case, there are three points of note:

This case's time when it happened is during a period of inadequate justice. There is no specific law to protect the environmental interests of other countries. The lack of attention to environmental protection led to the evil discharge of hazardous gases from this lead core factory for decades.

This factory was not a multinational, but more than an international. Although it is a geological location in Canada, its environmental effects spread across borders and the United States, causing damage to America. The $f$ also falls under the category of transboundary pollution. At that time, the definition of transboundary pollution was not clear, which led to the continuous occurrence of pollution.
It is challenging for victims to recover their compensation. At the beginning of this case, victims try to seek private recourse but failed because this is beyond the scope of domestic law.

This particular case makes no difference from others. They all cause environmental pollution in other countries, their victims struggle to recover their due compensation, and the vast majority of punishments are fines rather than substantive changes. Though not a multinational company, the case of the Terrell smelter has had repercussions elsewhere, and it has taken years to resolve it. The lack of law has led to tragedy, and the lack of regulation has $\mathrm{mThe}$ It easy for heavy industries, more often than not, to take advantage of it[13].

\section{CONCLUSION}

This paper expounds on the conflicts between the international investment protection system and the international environmental protection law. The conflicts are essentially the conflicts between the interests of transnational corporations and the public environmental interests of host countries and the conflicts between investment protectionism and environmental protectionism. After the 1970s, in the face of the accelerating process of economic globalization, MNEs have accelerated the speed of external expansion, and their operation has gradually integrated into the world economy. Their status and role have become increasingly important. The international community has realized that to promote MNEs to fulfill their responsibility of environmental protection; needs more norms from the international community. Due to the "soft law" nature of international normative documents and the lack of enforcement mechanism, as well as the severe shortage of traditional regulatory means to regulate MNEs to undertake environmental protection responsibility, how to more effectively restrict the social responsibility of MNEs is still a thorny problem faced by the international community.

With the growing strength of MNEs, people gradually realize that IIAs are supported to be a kind of governance system, rather than a unilateral commercial treaty to protect the interests of workers. With the deep development of the concept of sustainable development in international law in recent years, people increasingly expect to use the international investment activities of Chinese companies to promote the sustainable domestic development of host countries rather than simple economic development. Therefore, many scholars advocate that the global investment law should also guide sustainable development to realize the domestic social public interests of host countries and the profits of MNEs due to investment activities. It can promote the sustainable development of the host country. This paper argues that the coordination of these two legal conflicts should be mainly through the relationship between the 
international investment treaty and the international environmental protection law in the investment treaty. Therefore, it is of great significance for the future reform of the International Investment Law towards sustainable development to improve the enterprise environmental protection responsibility provisions in the international investment treaty. Therefore, there are still many theoretical and practical problems about the conflict and coordination between international investment protection rules and environmental protection rules, which need to be solved urgently. The researchers hope this paper can attract more experts and scholars to make joint efforts to conduct in-depth and detailed research on this topic.

\section{REFERENCES}

[1] Andreas Kulick, Global Public Interest in International Investment Law, Oxford: Oxford University Press, 2012.

[2] D.Bodansky,J.brunnee,E.Hey, The Oxford Handbook of International Environment Law, Oxford:Oxford University Press, 2007.

[3] Andres Rigo Sureda, Investment Treaty Arbitration: Judging under Uncertainty, Cambridge:Cambridge University Press, 2012.

[4] Rudof Dolzer, Christoph Schreuer, Principles of International Investment Law, Oxford: Oxford University Press, 2012.

[5] MontillaFernández, LuisTomás, Large Scale Land Investments in the least Developed Countries, Ha

[6] Jorge E. Vinuales, Foreign Investment and Environment in International Law, Cambridge: Cambridge University Press, 2012.

[7] Du Tongxin , Corporate Social Responsibility in International Investment Law.

[8] Cheng Liang: Research on employees' social insurance in foreign enterprises in China.

[9] Philippe Sands, Ruth Mackenzie, Cesare Romano, International Juducial Integration and Fragmentation, Oxford: Oxford University Press, 2013.

[10] Joost Pauwelyn, Conflict of Norms in Public International Law-How WTO Law Relates to other rules of International Law, Cambridge: Cambridge University Press, 2003.

[11] UNFCCC. national programs for activities implemented jointly under the pilot phase. At https://www.unfcc. .de/program/aij/aij._np.html.

[12] Reference Publications, Loewen loses
https:/www.FindArticles.com/p/articles/mi. _qa3923/is._200308/ai_n9278577.

[13] Sanford E. Gaines, NAFTA Chaper 11 as a Challenge to Environmental Law Making- One View from the United States, Conference Draft at https://www.envireform.utoronto.eec.c

22 Metalclad $\%$

20 case $\% 20 \%$ $20 \% 22$ scientific $\% 20$ evidence $\% 22 \% 22$. 